Comparative Philosophy Volume 4, No. 2 (2013): xxx-xxx

Open Access / ISSN 2151-6014

www.comparativephilosophy.org

\title{
NEOPLATONISM AND PARAMĀDVAITA
}

\author{
MICHAL JUST
}

\begin{abstract}
There has long been a debate on the possible similarity between some forms of Indian and Greek idealistic monism (Advaita and Neoplatonism). After a basic historical introduction to the debate, the text proposes that Paramādvaita, also known as Kashmiri Shaivism, is a more suitable comparandum for Neoplatonism than any other form of Advaita, suggested in the debate. Paramādvaita's dynamic view of reality summarized in the terms prakāśa-vimarśa or unmeșa-nimeșa, corresponds quite precisely to the viewpoint of Neoplatonism, summarized in the similar bipolar terms such as prohodos-epistrophe. The context of the dynamic nature of reality doctrine is also quite similar (svatahsiddhatva, authypostasis). My arguments are based on the texts of Plotinus and Proclus (Neoplatonism) and the texts of Abhinavagupta, Utpaladeva and Kșemarāja (Paramādvaita). Several parallel doctrines of both systems are further discussed: the doctrine of creative multilevel subjectivity, the doctrine of mutual omnipresence of all in all, the doctrine of creative multilevel speech, and some corresponding doctrines on aesthetic beauty and its important role in the Soul's return towards its ultimate source. Some implications of the high degree of correspondence between both systems are considered at the end of the paper, for instance whether some similarities of compared systems might be explained on a structural basis, since both schools ware facing similar sceptical critique (Mādhyamika, Hellenistic scepticism).
\end{abstract}

Keywords: Abhinavagupta, authypostasis, brahmāsvāda, comparative philosophy,

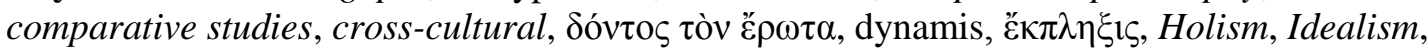

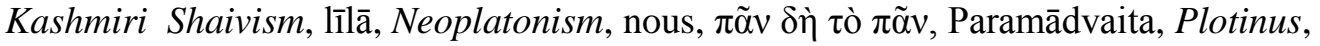
Plotinus and India, prakāśa-vimarśa, pratibhā, Pratyabhijñā, Proclus, prohodos-epistrophe, rasa, rasāsvāda, sarvamaya, sarvottīnna, Spanda, Spandakārikā, svataḥsiddha, tantra, theatrum mundi, Utpaladeva, Vijñānabhairava

The following text is a contribution to comparative studies of Greek and Indian forms of monistic idealism ${ }^{1}$, based on the texts of Plotinus (ca 204-270 AD) and

JUST, MICHAL: Department of Philosophy and History of Sciences, Charles University, Prague, Czech Republic. Email: suryadasa@gmail.com

1 I am deeply aware of the tentativeness of the term 'idealism', especially in connection with non western philosophy. Here, I mean it to point out, approximately, that cognitivity is an essential core for a given philosophical system and not just an epiphenomenon of something else. Further discussion in: Lusthaus 2002, 2 a. 
Proclus (412-485 AD), as well as Abhinavagupta (ca 950-1020 AD), Utpaladeva (ca 900-950 AD), and Kșemarāja (ca 975-1125 AD). Comparative studies of the monistic schools of Greece and India are not new. To name at least one classical study on the topic, let us mention Advaita and Neoplatonism by the Dutch Indologist J.F. Staal, which compares Neoplatonism with Advaitavedānta of Ādi Śankkarācārya. As far as I know, however, there has been no focused attempt to compare Neoplatonism with Paramādvaita (supreme Advaita), ${ }^{2}$ a branch of Indian non-dualism (Advaita) that originated in Kashmir, in the very north west corner of India. As the reader will see, Paramādvaita is in many respects a more promising comparandum ${ }^{3}$ than any other monistic school of India. Its essential stress on the dynamic aspect of the absolute makes it a far more suitable, but yet unexplored, comparandum to Neoplatonic monism, which is also a dynamic system rather than a static hierarchy. The conscious and reasoned choice of the Paramādvaita as a suitable comparandum to Neoplatonism is thus a primary scientific contribution of this paper.

In the introduction, I will briefly introduce Indo-Greek comparative studies with a focus on monistic schools, and summarize the discussion of the "Oriental hypothesis" of the origin of Neoplatonic philosophy. Although the search for such "influence" brought few substantial consequences, it provoked a detailed study of both Greek and Indian monistic systems and forced scholars on both sides to clearly formulate the essence of these systems; it thereby accidentally contributed to the establishment of comparative philosophy as such.

Next, I will present both Neoplatonism and Paramādvaita as dynamic monisms. The focus will be on the dynamic notions of both systems, such as those of creative outflow (prohodos) and return (epistophe), and, on the Neoplatonic side, the doctrine of the absolute as a power (to hen=dynamis panton), as well as, on the side of the Paramādvaita, notions of prakāśa - vimarśa or the doctrine of the essential nondifference of a power and its possessor (śaktiśaktimatorabhedatā). I shall also consider the general context of the above-mentioned insights, which is a doctrine of the self-established (svatahsiddha, authypostaton) absolute, which is again present in doctrines of both schools.

In the third section, I will detail similarities between the two systems under study, such as the doctrines of All in All and multi-levelled subjectivity, as well as some parallel aesthetic doctrines. I consciously declined to search for historical influences from both directions (although they are definitely not impossible) and so my arguments are based only on structural analogies.

Some further implications of the high degree of compatibility of both systems will be discussed in the fourth section. Although this article does not aim to resurrect the old discussion of the possible oriental influence on Plotinus and his philosophy, its conclusions might nevertheless provoke a deep reconsideration of it. This would perhaps attract not only the attention of philosophers, but of historians as well. Even

2 However, the Italian scholar Raniero Gnoli has reported some resemblance within the aesthetic doctrines of Neoplatonism and Paramādvaita. (Gnoli 1956, 47).

3 Comparandum used in the sense of participium necessitatis, i.e. what "is to be compared" or "what shall be compared." 
if we strictly insist on methodological abstraction from the question of influence, the conclusions of the article might provoke another highly interesting question: whether the similarities in these systems might be explained on a structural basis, namely by an inevitable interaction of a metaphysical notion of substance with a devastating sceptical critique.

\section{FROM THE ORIENTAL HYPOTHESIS TO COMPARATIVE STUDIES}

The debate over the possible Eastern - namely Indian, Persian or Egyptian influences on the philosophy of Plotinus, the founder of the Neoplatonic School, continued throughout the $20^{\text {th }}$ century. Since this debate has been summarized brilliantly at least twice, ${ }^{4}$ I feel no need to add to it. Instead, I will discuss some points related to our research which I think should not go without discussion.

The early formulation of the Oriental Hypothesis of the origin of Plotinus' philosophy depended on the presupposition of "Pure Hellenicity", which was to consist in rationality, clarity, and a sense of measurement or even "objectivity" in a protopositivist sense. Plotinus was subsequently thought not to fit in this frame, for at least two reasons:

First, his philosophy is subjective in its essence. Not only did he base all his philosophical conclusions on his own living experience, including his personal "merging in One", but in a way he was also the founder of the very notion of subjectivity in the western world. Second, in his doctrine of the absolute he abandoned the Hellenistic ideal of beauty consisting in the harmony of proportions in favour of the ideal of an absolute of unbounded power, the power of all (dynamis panton). The Neoplatonic absolute is the ultimate source of all harmonic proportions in beautiful things and the beauty is therefore not reducible to them. The philosopher's ascent towards the absolute is thus a way to the "beautiful beyond beautiful", to the source of beauty creating power. ${ }^{5}$

The history of the rise and fall of the Oriental Hypothesis is hence the history of the rise and fall of the presupposition of pure "rational" Hellenicity. Enormous work has been done in the history of antique philosophy since the 1950s, of which we must at least mention E. R. Dodds. ${ }^{6}$ Additionally, the pre-history of the Neoplatonic school itself, the middle platonic school, has been attentively researched and closely described since that time. ${ }^{7}$

The French antique-philosophy scholar E. Brehier, who identifies the source of the "foreign element" in Plotinus as the teaching of the Indian Upanishads, ${ }^{8}$ was an earnest advocate of the Oriental Hypothesis. Brehier's conclusions were opposed by A.H. Armstrong in his article "Plotinus and India"9 where he argues that even if we

4 Wolters 1982, 293-309; Staal 1961, 235-246.

5 Enn. V.8.8.

6 Dodds 1953.

7 E.g. Merlan 1953, Dodds 1928.

8 Brehier, 1936, 116-118.

9 Armstrong 1936, 22-28. 
accept Brehier's view on Plotinus, there is no need to go as far as India or even to leave the Greek world to find its predecessors. So although the Indian influence on Plotinus is not "absolutely impossible", its postulation is methodologically doubtful. Yet there is another phase of the Oriental hypothesis that partially leaves aside the concept of "Pure Hellenicity" and focuses on the texts themselves: this phase is perhaps best represented by another French scholar, J. Filliozat. His method consists of a close reading of given Greek and Indian philosophical or medical texts to search for mutual parallels, with a subsequent discussion of their cultural and historical contexts.

The aforesaid focus on the texts themselves brings another shift in the discussion and gives birth to the establishment of Indo-Greek comparative studies, wherein the question of historical influence is usually set aside in favour of seeking structural or doctrinal parallels of the two systems. In these attempts, however, Neoplatonism generally maintains its role as the Greek comparandum to the Indian systems, beside the sceptic school which is often compared to some branches of Mahāyana Buddhism.

The key early contributions to such comparative studies include, in my opinion, J.F. Staal's monograph Advaita and Neoplatonism and Indologist P. Hacker's Cit and Nous in Advaita and Neoplatonism. ${ }^{10}$ In subsequent part of this paper I will take up some of their ideas, but let me first mention some points of disagreement as well.

In his work, Staal sees an essential difference between Advaita and Neoplatonism in their notions of the absolute: whereas the absolute of Neoplatonism is a potential infinity, the absolute of Advaita is an actual infinity. ${ }^{11}$ But in fact, these claims fail to describe reality better than their opposite. ${ }^{12}$ At the very least, the absolute of both Neoplatonism and the Paramädvaita branch of Advaita is a dynamic and pulsing one: from the pole of potential infinity to the pole of actuality and back again - as we will see in the subsequent parts of this paper and as an attentive reader of the texts of both traditions can see for himself. This dynamic, living, pulsing absolute is the very core of the teaching of both traditions, and any comparison which avoids this fact on either side of its comparandum is missing an important point of its subject.

Stall's supporting argument for the potential infinity of the Neoplatonic absolute is the Greeks' traditional fear of the formless and unlimited. This may be true for Hellenes in general, but it is quite doubtful for Plotinus, who "argues in terms shocking for traditional Hellenic thinkers as the source of Form, Measure and Limit, the One must itself be Formless, Unmeasured, and Infinite". ${ }^{13} \mathrm{We}$ see this, for example, in VI.7. where the beauty in beautiful things is characterised as the splendour of the Good, while the measurable symmetry just as its "by-product". 14 Thus the core of Staal's misunderstanding is the very claim of an "actual" or

10 Staal 1962, Hacker 1977.

11 Staal 1961, 181.

12 See e.g., The One is all things (in a transcendent mode): Enn. V.2.1.2., VI.8.18.32-41. The One as pure act: Enn. VI.37.15-16,VI.9.6.50-5.

13 See Wallis 1972, 57.

14 Enn. VI.7.22.21-24. See also Hadot 1993, Ch.IV.

Comparative Philosophy 4.2 (2013) 
"potential" character of anything in Neoplatonism, since its clear doctrine is that everything is actual in itself while potential in all other things. ${ }^{15}$

Although I appreciate the clarity of P. Hacker's argument, where he putatively identifies the Advaitic cit (consciousness) with the Neoplatonic nous (intellect), I disagree with one conclusion of his paper, where he over-evaluates the Advaitavedānta notion of an empty, absolute, pure reflectivity as embodied in the notion of cit, and on this basis compares it with the Neoplatonic nous, which, being a complexity of forms, is neither absolutely "empty" nor "pure". From such a perspective, Neoplatonic teachings look like an imperfect step towards an aim that is perfected in Advaitavedānta. And on this point, I must express disagreement: Neoplatonism certainly knows the notion of an empty, absolutely pure subjectivity, as does our suggested comparandum the Paramādvaita, but both avoid making it the basis of the system for sound, well-argued reasons. ${ }^{16}$ Briefly summarized, the absolute of the above mentioned school is a living one; as such, it cannot be treated only as a reflective "emptiness" for it is simultaneously a creative "fullness".

Let me make one final note on the putative identity of the Advaitic cit cited above, and the Neoplatonic nous. The very possibility of establishing such an identity and of receiving meaningful outputs is opened by the non-obvious common base of both traditions, which lies in metaphors common to both systems, and which can be founded in their older referential strata, i.e. the Upanishads on the side of Advaita and the Corpus Platonicum on the side of Neoplatonism.

Let me now select just one parallel, perhaps the most striking one. It is a common metaphoric basis of the notion of Soul. In the referential strata of both traditions, we find the metaphor of Soul as a composite of yoke of horses and chariot with driver. The horses represents the passionate or sensible part of the Soul, yoked to a vehicle of

15 See also Section 3.1 of this article.

16 The topos of śünyatā is considered in the Paramādvaita point of view, for example, in commentaries to SK 12-13. Sp.S. (Transl. Singh, 1980,76): "The Supreme Lord himself, in order to conceal real knowledge, shows fools void as reality so that they may accept it as the goal to be achieved."

Kallaṭa writes in his vṛtti: abhilāpasamyogāt sā śūnyāvasthā atītā mama iti smaryate, na ca àtmasvabhāva eșaḥ, yasmāt na tvevam cidrūpatvam mūạhāvasthāvat smaryate, tasya sarvakālamanubhavitṛtvenānubhavo nityoditatvāt (MBDL, line 1201-3.)

When the state of sunnya is being remembered as an experience "that happened to me" as in any other case of continuity of experience, it cannot be the nature of atman, since this nature is not something that could be remembered, such is the case of empty (and therefore) unconscious experience because at any time of experience there is an experiencer of it.

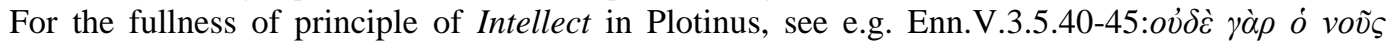

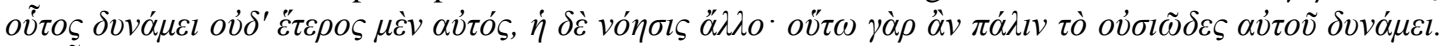

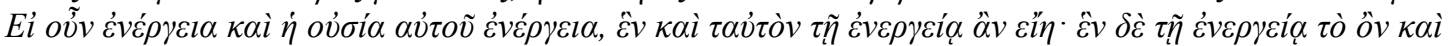

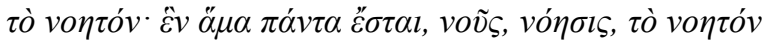

"... For that primal principle is no potentiality and cannot be an agent distinct from its act and thus, once more, possessing its essential being as a mere potentiality. As an act - and one whose very being is an act - it must be indistinguishably identical with its act." Transl. Kenna 1969, 324 . 
the psycho-physical body, where the real core of the Soul is the driver, the charioteer: the very top of intellectual part the Soul. ${ }^{17}$

I do not feel the need to further stress the striking presence of such parallel topos in the core of the textual base of both systems. In my opinion, its very fact is eloquent enough. Even the broader appeal of this metaphor is the same in both systems: to show that hegemony over the sensual and passionate parts of the soul-body vehicle is gained by sustained knowledge and training, whose mastery is symbolized in the metaphor of the yoke in the hand of the charioteer. As far as I know, this metaphor is rarely, if ever, used as a basis of a philosophic comparison, although it would definitely deserve close attention.

\section{THE ESSENTIAL DYNAMIC NATURE OF NEOPLATONISM AND PARAMĀDVAITA}

\subsection{NEOPLATONISM AS A DYNAMIC MONISM}

In Plato's Sophist, there is a passage discussing the nature of being. It starts from the usual platonic difference of unstable becoming belonging to bodies, and of being belonging to the Intellect and Soul. From this preliminary step it would appear that the sphere of being is devoid of any motion at all and, as surprised Plato shows, therefore of life as well. But this contradicts the general platonic intuitions about the nature of God and the absolute, namely, that this is not only a culmination of being but also of beauty, considered as a living creative force. Thus in Sophistes, before he admits motion and life in the sphere of being, the Stranger puts a rhetorical question:

But for heaven's sake, shall we let ourselves be easily persuaded that motion and life and soul and mind are not really present to absolute being, that it neither lives nor thinks, but awful and holy, devoid of mind, is fixed and immovable? ${ }^{18}$

Plotinus explored this thought quite extensively. The absolute, and to some extension also all other subsequent levels emanating from it, is endowed with power, whose first characteristic is life. The Intellect of Enneads is "boiling with life"19 and later Neoplatonists made this life of the Intellect an outflowing phase of a trinity, the Intellects' self-establishing movement (Being-Life-Intellect). ${ }^{20}$

An important remark should be made about the relationship of this power to its source. It is not just an arbitrary quality of a given substance, but an essential characteristic, which is, according to Plato, a quality defining its holder in such a substantial way that he would "either go away or vanish" if somehow it could be taken away from him, as it happens e.g. with snow and fire. ${ }^{21}$ The very same thought,

17 Corpus Platonicum: Phdr. 246A6-7, Upanishads: KathUp.III.3, Radhakrishnan 1994, 246.

18 Soph. 248e-249a. (Tr. by Fowler, 1921.)

19 Enn .V.5.12.9.

20 See ET.103. Also: In Tim. I.371.15-25.

21 Phaed.100c-104c. 
using the same simile of snow and fire, is used by Plotinus when he describes the power of the One:

Even lifeless objects impart something of themselves, as far as they may; fire warms, snow chills, drugs have their own outgoing efficacy; all things to the utmost of their power imitate the Source in some operation tending to eternity and to service. How then could the most perfect, the First Good, remain in itself, as if it is grudged to give of itself, or was impotent (adynaton), when it is the productive power of all things? $?^{22}$

The One of the Plotinian system, perfect and self-sufficient, is endowed with power, overflowing from its source and creating subsequent levels. ${ }^{23}$ First so created is the Intellect, which is fully established only when it turns back contemplatively towards its source, the One. In the same way, the Intellect creates a last selfestablished substance, the Soul, which is again established as such only after its turns back to its source, the Intellect. The first phase of this creative circular movement is thus a kind of formless outflow, whereas the second phase is self-forming perfection by backwards movement towards its own source. This attempt fails for structural reasons, but leads to self-reflection, which is a perfection of self-establishing movement. The first of these phases is poetically called Intellect in love, whereas the second Contemplating Intellect. ${ }^{24}$ This movement of creation cannot stop until it reaches the level of matter, which is incapable creating anything further. ${ }^{25}$

Plotinus treated the aforesaid cyclical, hypostatical movement using two technical terms: unformed procession (prohodos) and forming return (epistrophe). This became part of the generally accepted Plotinian heritage in later Neoplatonism, which adds a third phase of "remaining in itself" (mone) thus forming a trinity of remaining procession - return. This would become a universally applied triadic pattern for establishing different levels of the increasingly complex system of late Neoplatonism. Even if we focused on nothing but the dynamics described by procession and return, the dynamic character of Neoplatonism would nevertheless be revealed in all its fullness and clarity.

One can perhaps make an objection about the essential dynamic nature of the first principle, the One. Can this principle be called dynamic when by definition it is single? The answer should take the structure of the system into account. Evolution does not take place outside the One but inside it. Moreover, as we shall see in the following part, the Plotinian system is holistic, which means that the higher principle is present within its evolute, in accord with its mode. The one in us is, in its own way, the One, the power of all, much in the same way as the individual Soul has a potential to be her sister, the world Soul, and both have the potential to ascend to their undescendened source, the Intellect.

22 Enn. V.4.1.34-5. (Tr. by Armstrong, unless indexed otherwise)

23 Enn.V.2.1.7

24 Enn. VI.7,35

25 Enn.IV.8.6. V.2.2. See Wallis 1972, 65. 
This radical holism was criticised by later Neoplatonists, as was the metaphysical optimism about the nature of the human Soul, which is in its upper part undescended and eternally seated in the Intellect. But the pulsating creative character of the absolute, including the two subsequent self-constituted emanating levels of Intellect and Soul, was accepted and left untouched, at least as a basic structure that can nevertheless undergo further divisions increasing its complexity. Thus Proclus summarizes the creating process of all self established levels (authypostasis) : "Whatever is complete proceeds to generate those things which it is capable of producing, imitating in its turn the one originative principle of the universe."26 And, "Everything originally self-moving is capable of reversion upon itself." 27

\subsection{PARAMĀDVAITA AS A DYNAMIC MONISM}

By the term Paramādvaita, we refer to the non-dual teaching of Kashmiri Śaivism as it culminated in the schools of Pratyabhijña (recognition, specifically of one's own divine nature) and Spanda (vibration, specifically of consciousness) as it was summarized in the work of Utpaladeva, Abhinavagupta and Kșemarāja.

The schools of Pratyabhijña and Spanda developed a theory of an essentially dynamic, pulsing absolute, in contrast to the motionless "pure mind only" absolute of Advaitavedānta and some Mahāyāna Buddhist schools. To understand this notion of a dynamic absolute, we must first consider how pulsation is the very base of it. The static and dynamic poles of reality are usually treated as God, the possessor of power (śaktimān), and his power (śakti), respectively. In most philosophic systems connected with mainstream orthodox Hinduism, the relation of these two poles is a hierarchy with God, the static masculine pole of reality on the top. But the Paramādvaita schools are, in fact, a philosophical output of tantric Hinduism wherein the dynamic feminine aspect of reality is valued much more highly, and thus power is equal to, or even higher than its subject, which is defined by it. The absolute of the tantric systems is not the culmination of purity, but the culmination of power. ${ }^{28}$ Freedom, as a characteristic of the absolute of such a system, is not empty apophatic "freedom from", as in e.g. Sāmkhya or Advaitavedānta, but active kataphatic, "freedom to".

The first rule to be remembered when talking about the Paramādvaita notion of the dynamic absolute is the doctrine of the essential non-difference of power and its holder (śaktiśaktimatorabheditatva). At this point, we again occasionally encounter the "platonic" simile of the essential oneness of heat and fire or cold and snow. ${ }^{29}$ In Pratyabhijūa kārikē we read:

The very life of insentient beings is based on sentient ones. The life of sentient beings is considered as the power of knowledge (jñanna) and the power of a creative act $(k r i y \bar{a})$. Of

26 ET 25 Dodds, 1963, 19.

27 ET 17 Dodds, 1963, 29.

28 See Sanderson 1985.

29 V.Bh. 18-19a 
them, the power of knowledge is self-established (svatah siddham) seated in a body with power to act. $^{30}$

This power of knowledge projects the content of mind as in a dream or within the visions of yogins. ${ }^{31}$ In fact, this creative power is Siva, the absolute, who - even in an embodied being - never ceases the five characteristic activities (pañcakrtya) of creating, maintaining, destroying, concealing and revealing. ${ }^{32}$ As an embodied being, he does so by creating, etc., the content of mind in the creative sequence (krama) of conscious flow. ${ }^{33}$ But this creative activity is no illusion, the mental content it creates is by no means unreal, as is the māya of Advaitavedanta despite the fact that both schools hold the doctrine that "everything is mind only". ${ }^{34}$ Rather, the created world is a real product of will (icchā) and creative potential $(k r i y \bar{a})$, which are both expressions of the freedom (svatantrya) of the absolute. This is the "realistic" aspect of Paramādvaita. It is a natural consequence of the paradoxical doctrine of the fully uncompromised transcendence within the fully uncompromised immanence (sarvamaya - sarvottîna) of Siva. ${ }^{35}$ In fact, nothing that is not of the nature of the light of consciousness can ever enter it. To be is to have the nature of consciousness ${ }^{36}$ and so there is no need for the separate categories of Sat and Cit as in Advaitavedānta.

The dynamic nature of the absolute, which even occurs within a single cognitive act of man, imprisoned as he is in the unstable stream of relative being (samsāra), is described in Pratyabhijñ $\bar{a}$ by the notions of prakāsa, the light of projecting awareness, and vimarśa, the light of reflective awareness. ${ }^{37}$ The point of Pratyabhijñ $\bar{a}$ is that if, as in most other systems e.g., Advaitavedānta, the absolute is light only, sans the pole of reflective awareness, it would then be a lifeless entity, e.g. a crystal or a lamp. ${ }^{38}$

30 tathā hi jaḍabhūtānām pratișthā jīvadāśrayā, jñānam kriyā ca bhütānām jīvatām jīvanam matam, tatra jūānam svatah siddham kriyā kāyāśritā satī. (IPK I.1.3-4.)

31 cidātmaiva hi devo 'ntah sthitamicchāvaśädbahih | yogīva nirupādānamarthajātam prakāśayet (IPK I.5.7.)

32 IPK I.6.7.(tadevam vyavahāre'pi prabhurdehādimāviśan | bhāntamevāntararthaughamicchayā bhāsayed bahih) also Sp.S.: evam ca vyākhyāte sati yat pañcavidhakrtyakāritvam śrīsvacchandādiśāstreșu parameśvarasya ucyate Dyczkowski, MBDL (2005), line 292.

33 The doctrine of vibrating consciousness in sequence of sense perception is another jewel of Paramādvaita, its exposition would extend this article beyond a reasonable limit. For further readings, see: TS. IV.Ah. 29, 1.1-4,. KSTS.,TA IV. 121-189., Sanderson, 1990, 681-685.

34 SKV 29.: ..manmayameva jagat sarvam. (For him everything is just a play, who knows that...) Everything is of the nature of mind only...

35 SKV 55.: ...sarvottīrnacinmātravișayo viśvamayaśakticakravișayaśca... The transcendent aspect (of Siva) is pure consciousness; whereas the immanent is the circle of energies, see SK 1.1. below.

36 IPVV: I. 220: astitvam prakāśamānatvameva. For further references on parmādvaita ontology see Torrela 1994, 15-20. Dyczkowski 1989, 51-57.

37 In depicting vimar's a as 'reflective awareness', I follow the translation of R.Torella, which seems to me much more accurate than e.g. K.C.Pandeys' 'freedom'. Still it is to be remembered that vimarśa although "reflective" is an active power! That is why sometimes it is called e.g. intuition (pratibhā).

38 IPK.I.5.11. svabhāvamavabhāsasya vimarśam viduranyathā | prakāśs'rthoparakto'pi 
In the Spanda school, we find a declaration of the dynamic nature of its absolute in its very first line: the basic text, the Spandakārikā, begins with the verse: "That one, which by opening and closing of eyelids, is creating and destroying the world and who is the lord of the circle of powers, we praise." 39 As commentators have explained, the opening (unmeșa) and closing (nimeșa) of eyelids are technical terms of creative expansion and contraction of consciousness, which is called spanda (the throb, vibration). The source of the universe is never without this power (na tvaspandah). ${ }^{40}$ Lets note that the general context of such creative pulsating process is again self-creation (svatahsiddhatva), since there is nothing outside absolute (ekaśivatā $)^{41}$

One of the original points of the Spanda teaching is that expansion and contraction take place simultaneously: the expansion of the universal consciousness is just another side of the contraction of a particular samsārical consciousness and vice versa. ${ }^{42}$ This vibration goes on, not only in the great cycles of creation (srssti), maintenance (sthiti) and withdrawal (samhṛti) of the universe, but also in each cognitive act, each single thought followed by another throughout our daily samsārical activity. Thus according to both of these schools, Siva, the dynamic absolute, is uncompromised in his freedom, even while present at the very core of our individual Soul, where he performs his essential activities. The task of human existence is thus to realize that our innermost nature (svasvabhāva) is identical with the universal creative nature of the absolute and therefore, in an ultimate sense, free. ${ }^{43}$ Although this all sounds much like the Upanishadic dictum on the identity of the human Soul (ätman) with the universal principle of existence (brahman), it fills this old form with new content, stressing the essential dynamic nature of both, in fact identical, principles.

\section{SOME CORRESPONDING DOCTRINES OF NEOPLATONISM AND PARAMĀDVAITA}

\subsection{ALL IS IN ALL}

As we have seen in 2.1, the dynamism of the Neoplatonic One is carried through on each level of its hierarchy. On every level, it is realized by the phase of out-flowing potency, which subsequently turns towards its source thus creating itself in its fully formed shape. The ultimate source of this potency is the Neoplatonic absolute, the

sphațikādijaḍopamah Dyczkowski, MBDL (2005), line 8037.

39 SK I.1. yasyonmeșanimeșābhyām jagatah pralayodayau | tam śakticakravibhavaprabhavaì śamkaram stumah $\|$

40 SpN, Singh, (1980), 6.

41 See n. 30 and 55.

42 Sp.S. p. 9 (KSTS). Cit. in: Dyczkowski 1987, 61.

43 satyam, paramārthato na kaścid bandhah kevalam svasmādanuttarāt svātantryāt yadā svātmānam saṃkucitamavabhāsayati sa eva IPVV, Dyczkowski, MBDL (2005), line 23821. 
One, but its self-creative power is "delegated" to all subsequently created levels of Intellect and Soul.

Every ontological level is thus in its own way present on a lower plane, which is again in its own turn present on a higher one. Generally summed up by Proclus: everything exists as a cause (kat' aitian) on its higher level, as a substance on its own level, (kat' hyparxin) and as a participated unity (kata metexin) on the subsequent lower level. ${ }^{44}$

The mutual presence of all in all is not limited to the vertical axis of the Neoplatonic system, but is present on each self-established level. The paradigmatic level on which Plotinus develops his doctrine of the holistic interconnection, and even interpenetration, of everything with everything else is the Intellect.

...each part (of Intellect) whichever one you take, is all things, but perhaps in different ways. For it is actually one thing, but it has power to be all....

In his contemplative manual describing the epistemic structure of the Intellect, he writes:

Let us, then, make a mental picture of our universe: each member shall remain what it is, distinctly apart; yet all is to form, as far as possible, a complete unity so that whatever comes into view shall show as if it were the surface of the orb over all, bringing immediately with it the vision, on the one plane, of the sun and of all the stars with earth and sea and all living things as if exhibited upon a transparent globe. ${ }^{46}$

In this way he stresses, in a wonderful mental experiment, the mutual interconnectivity and interpenetration in the intellectual realm. But even on the level of the Soul we can find traces of this mutual interpenetration, as we can see in the case of language or of science, where each sentence only makes sense when we take into consideration the whole of the language or of science, i.e., in all other possible sentences of a given system. ${ }^{47}$ The border of mutual interpenetration is within the Soul, as it copies the line of the presence of logos; and so only the lowest, most irrational part of her, the alogon of an individual Soul and the fyzis (nature) of the world Soul, are characterized by mutual exclusion, which we can observe e.g. in solid objects. This corresponds to the general Neoplatonic doctrine of a gradual limitation of the Absolute. Wherein logical difference belongs to and limits the Intellect, time difference belongs to and limits the Soul, and the spatial difference belongs to and limits the body. ${ }^{48}$

Plotinus's holism reaches its peak in VI.4. In this essay, he examines the topic of immanence: in what way the Intellect is present within us? Does it do so by a kind of

44 Enn. III.4. Summarized by Proclus in ET. 65.

45 Enn. VI.7.9.33-35.

46 Enn. V.8.9. Kenna 1969, 361.

47 Enn. V.8.4., V.9.8.

48 We can find a parallel doctrine of a voluntary limitation of the Absolute in Paramādvaita, where the gradual limitation is done by six "hazes" (kãancuka) of the Absolute, see IPK+IPKV, III.2.4-19. 
gleam it creates on a lower level of Soul with itself remaining on its own higher plane - or is it present in all its mighty power and splendour wherever it exists, even at its creation? In VI.4., Plotinus's answer favours the latter. ${ }^{49}$ The true "All", i.e. the Intellect, cannot be bereft of its power, even when it is present on a lower ontological plane, i.e. the Soul. ${ }^{50}$ The same thought can be applied even to the One itself, thus leaving the Plotinian system devoid of hierarchy in favour of strict holism. The human Soul can thus travel to the intellectual realm, which she in fact has never left (the doctrine of the undescended Soul) and can even, rarely, (Plotinus himself succeeded but a few times) reach oneness with the top of the hierarchy, the One.

The mature formulation of holism in the Neoplatonic school is All is in all but each according to the mode of its own existence. ${ }^{51}$ The stress on the first part of the maxim is peculiar to some holistic tendencies in Plotinus' thinking, whereas the stress on the second, and corrective half, is peculiar to the later Neoplatonism of Proclus, who made the system more rigid and the borders between its levels firmer and clearer, but also impenetrable. According to Plotinus, the levels of ontological hierarchy correspond to the philosopher's stages of mind, whereas according to Proclus, they rather correspond to all possible logical differences.

Let us now turn our attention to the Paramädvaita, where we also find a maxim on the mutual interpenetrative presence of all in all (sic!). The verbatim it is: "everything is of the nature of everything" (sarvam sarvamayam). In Paramädvaitic texts, it appears as a traditional saying of the school. I have encountered this maxim here and there in the texts of Paramädvaitic schools, mostly in commentaries of Kșemarāja and Abhinavagupta. I still have no clear understanding of its origin and prehistory, ${ }^{52}$ but I guess that it is a part of a large cluster of Mahāyanna-Buddhist doctrines inherited by Paramādvaitic authors, of which some were refuted, some reworked, and some simply taken over. ${ }^{53}$

The maxim is not only nearly identical to the translation of the Greek pasa en pasin, but its doctrinal context is also quite similar. In his commentary to SK 1, Kșemarāja describes Spanda, the creative pulse of Siva, as the absolute. It is a wave of consciousness that proceeds from the purest and ontologically highest levels to the level of everyday samsāric existence and back. According to Kṣemarāja, Śiva in his freedom, expands "in the process of gradual descent. (He) displays by way of playfully concealing his inner nature, the succeeding aspect by suppressing preceding ones". Then he returns again by giving up concealment to reach his higher form, in an interplay of expanding and contracting consciousness. So, in this way "he shows

49 Thus being one of the strongest criticisms of emanation metaphoristics, which is otherwise used in some places in Enneads.

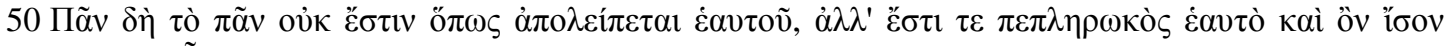

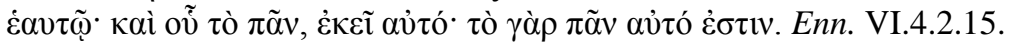

51 ET 103, Dods, 1933, 93. For the history of the maxim, see also ibid, p. 254.

52 For some suggestions see Torella 2002, 15, fn. 12.

53 Many of these interactions are described in R.Torella's notes to Íśvarapratyabhijāākārikā and vrtti (Torella 2002). The actual identity of the Buddhist doctrine sarvam sarvamayam and the Neoplatonic pasa en pasin is already noticed and discussed in Evilley 2002, 576-579.

54 Sp.N. 11, Transl. In Singh, 1980. 
everything as of the nature of everything else". It should be said that the mutual interpenetration described by the maxim in the Paramädvaita is just another face of the doctrine that Everything is Siva (ekaśivatā). ${ }^{55}$

In Abhinavagupta's Paratrisikavivarana, we again find the maxim everything has the character of everything, but here it is in a linguistic context. As with Plotinus, language $(\log o s)$ is a platform where interconnection of all is seen most clearly by us as human beings. Influenced by tantric speculations on the nature of speech ( $v \bar{a} c)$, Abhinavagupta uses a slightly different strategy. Thus, in the example of the sentence 'I, Mr. X.Y., am speaking', he shows that the subject of the sentence is in a way objectified, and is in fact thereby of a mixed nature: that of the first grammatical person $(\mathrm{I})$ and that of the third $(\mathrm{He})$. And again, in the sentence 'Listen to me, $\mathrm{O}$ mountains' the grammatical form is the second person (You), but in fact the assumptive listener is an object, as it is of the nature of the third grammatical person (It). This is according to tantric doctrines wherein, grammatically speaking, the first person belongs to Śiva (God), the second to Śakti (power) and the third to nara (human). All is in a way mixed on the level of language, which is, according to Paramādvaitic doctrines adopted from the grammarian Bhartrhari, the basic level of any experience at all.

Another adopted Bhartrharian doctrine is that of the fourfold speech: the transcendental (parā), the intuitive (paśyantī), the mental (madhyamā) and the voiced (vaikhari $)$, a doctrine that can also serve as a basis of exposition of the maxim everything has the character of everything. Though we use voiced (spoken) speech in everyday communication, any such event of creating or understanding a sentence also puts our inner mental speech to use. And to do this, we use intuitive speech, which is an outflow of the supreme level of speech, the parā.

There is also a quite surprising parallel between the doctrine of multi-levelled creative speech in Neoplatonism (logos) and Paramādvaita (vāc), but for brevity's sake no independent part will be dedicated to this topic in this article. Abhinavagupta demonstrates that the Spandic pulse of consciousness, from pure content-less consciousness (nirvikalpa samvid) to a workaday consciousness with a fully developed content (savikalpa samvid) and back, can also be described as the pulse of speech. Each part of this consciousness/speech chain has all the others hidden within, in a contracted form, itself being the open expanded form of its own kind.

The very same playful game of concealing and revealing of the form in the pulse of creative flow can be found in both Paramädvaita and Neoplatonism. The higher level in the pulse of prohodos and epistrophe contains its lower evolutes in its hidden (krifyos) form as cause (kat aitian); the lower level is the openly revealed (adiakrifos) potency of the higher and vice versa. ${ }^{56}$ It is a doctrine we have already met, e.g. in

55 SK 29: tasmācchabdārthacintāsu na sāvasthā na yah śivah.

56 TP, III.39.20-24: "plurality is in first members hidden and uncovered, in subsequent members already openly uncovered, as much as something is closer to the One, that much it hides and covers its

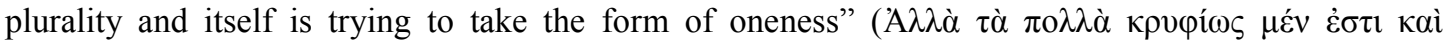

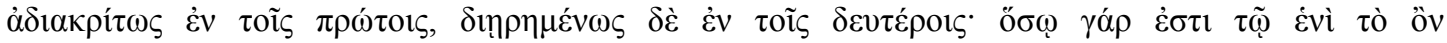

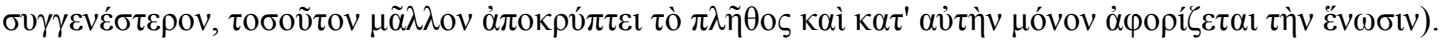


Section 1.2., "everything is itself in actual modus while all other things in potential modus".

\subsection{MULTILEVELLED SUBJECTIVITY}

Plotinus made the very concept of the conscious 'we' a philosophical problem for the first time in the history of the Western philosophical tradition, thereby discovering subjectivity for the Western world. He was the first Greek philosopher to systematically reflect the fact that our 'we' is a non-obvious, multilevelled entity, which varies with time and circumstances. ${ }^{57}$ Roughly expressed: the Soul's actual state is determined by what she contemplats. ${ }^{58}$ R.T. Wallis sums it up by quoting Plotinus: "from the dynamic standpoint 'we' are identical with the level to which we give most attention". 59

Plotinus was also the first to systematically observe the fact that there may be, and usually is, a long-term delay between emotionally charged experiences and their subsequent fruit. He identified two kinds of memory corresponding to judgement and the habitual reactivity of mind. ${ }^{60}$ In the same way in which the integrity of knowledge is actively mediated by Idea, a traditional topic of Platonism, Plotinus also turns his attention to personal integrity, which presupposes some higher kind of a conscious whole, which for Plotinus is Intellect. Whether or not we are aware of it, Intellect always "intelligizes". ${ }^{61}$ Since one part of our Soul stays undescended ${ }^{62}$ in the Intellect, there is also one part of our personality that is always intellectually active whether or not we are aware of it. When we identify with this highest level of our personality we are only potentially, but not actually, our normal daily "we", 63

Sometimes, even our activities are not accompanied by normal daily awareness (antilepsis, parakolouthesis) but only by an immediate sense of the present moment (synaisthesis), and are performed spontaneously without the delay of discursive thinking, understanding, etc. ${ }^{64}$ This immediate presence in action is evaluated by Plotinus as a more "concentrated in itself" modus of being ${ }^{65}$ and characteristic of the way of wise man (spoudaios). ${ }^{66}$

Let us turn to the Paramādvaita at this point where we are advised to contemplate spontaneity as characteristic of the higher realms of being when it occurs in activities

See R.Chlup, $2009,96$.

57 A classical passage is, e.g., Enn. VI.4.14.16; for further reading, see Hadot 1993, Ch. II., or Merlan $1953,77-84$.

58 Enn. IV.3.8.15

59 Wallis, 1972, 72.

60 Enn. IV.3.28.

61 Originally an Aristotelian doctrine. On this base P. Merlan (Monopsychism Mysticism and Metaconsciousness) identifies that as a source of Plotinus' doctrine of metaconsciousness.

62 Enn. IV.8.8.1-6.

63 Enn. IV.4.2.3.

64 Enn. I.4.10.21.

65 Enn. I.4.10.30-35.

66 Ibid. 
of our daily samsāric life. It is mostly in activities done spontaneously, with full focus, not reflected by discursive reason. In Spandakārikā we read: "Spanda is stable in the state one enters when extremely angry, intensely excited, running or wondering what to do." 67 The commentator adds, e.g., that running "refers by implication to all functions of the organs of action ... including speech ... or when one sings or plays a flute". 68 There are also numerous verses from a meditative manual of the Paramādvaita, the Vijñanabhairava, that refer to this practice, some of which are cited by commentators in connection with the aforesaid $k \bar{a} r i k \bar{a}{ }^{69}$

As we stated in the introduction, we do not intend to search for "influences". But let us say that the topic of multi-levelled subjectivity was at the centre of philosophical attention in India for centuries before Plotinus. And it reached conclusions very similar to Plotinus, which were developed in notions of samskāra (the memory trace of experience) and vāsana (its contracted form, empowered by direct influence on the behaviour of the mind) as tools for describing the determinative function of the unconscious mind, or notions of atman (the Soul, in its highest most general form), buddhi (intellect), ahamkāra (the ego sense), manas (mind), as tools for describing the cognitive structure of consciousness from sense perception right up to the "metaconsciousness" of pure the reflectivity of atman. All this was done long before the rise of the Paramādvaita and became a part of a common heritage of nearly every philosophical school of India.

Paramādvaita authors merely took some part of this heritage, although in some instances with some doctrinal adjustments. Thus, i.a. the overused atman is sometimes replaced by a more dynamic and intimate "one's own nature" (svabhāva). The enemy-number-one of all orthodox schools, the ego, was dichotomized into the artificial "I-ness" (krtrimā ahamttā) and pure "I-ness" (pürṇāhaṃtā), where the former bears some characteristics of the old ahamkāra which should be dissolved by yogic practices, whereas the latter is, in fact, the subjective side of the absolute and therefore, in its way, the subjective top of the epistemico-ontological hierarchy. And yet, even the lower levels of subjectivity are not to be dissolved or destroyed if they are viewed with correct understanding (sat tarka), merely as a play (līla, krị̂a $)$ and an expression of the freedom (svatantra) of the absolute. In the ultimate sense (paramärthatah), nothing at all is to be destroyed (heya) in the Paramädvaita, as it is to be in classical yoga or in Advaitavedānta, and thus its authors could openly declare that their new path is easy. ${ }^{70}$

In fact, for each level of the Paramädvaita universe, there exists a correspondent subjective pole experiencing this level. The hierarchy of those subjects or observers goes from the ultimate observer (parāpramātr) through the void observer (śünyapramātr), the observer of vital energy (prānapramātṛ) upward toward the bodily versed observer of the body in the world of illusion (dehapramattr,

67 SK, I.22. transl. Dyczkowski , 1992, 100. ...atikruddhaḥ prahṛșto vā kị̣ karomīti vā mṛśan dhāvan vā yatpadam gacchet tatra spandah pratișthitah...

68 Spandavivrtti, Transl. in Dyczkowski, 1992,101.

69 V.Bh. 101, 71, 118. Cited by Kșemarāja in SpN, Singh, 1980, 103.

70 IPK, IV.16: ...iti prakațito mayā sughaṭa eșa mārgo navo mahāgurubhirucyatesma śivadrsștiśāstre... 
māyapramātr). This hierarchy is perhaps best expressed by the groups of presiding observers ${ }^{71}$ at different levels of the Paramädvaita's universe, parallel to the classifications of 36 Paramādvaitic categories (tattva) from Siva, the absolute, to the everyday world of the senses and gross elements.

This doctrine of multi-levelled subjectivity, beside its doubtless contribution to psychology, also plays the role of an important regulative, which protects the system against the solipsist narcissism of single subject dreaming out its own world in both systems: In the wonderful play of creation, we are normally aware of and situated in our day-to-day consciousness. Its content is indeed projected by "us" but we are not usually aware of this fact because that projecting 'us' is operating on a far higher or deeper level than the level of our everyday consciousness.

\subsection{SOME PARALLEL DOCTRINES IN AESTHETICS}

Although "we" are in this way projecting "our" own content of consciousness, it is ever new for us and never ceases to surprise us. This characteristic is, according to the Paramädvaita, due to the spontaneous outflow of the power of creative intuition (pratibha $)$, which is another name for the dynamic reflectivity of consciousness (vimarśa). As with all other main activities of the absolute, it is ever present, even on the level of an embodied subject. ${ }^{72}$ Its presence can be observed in the human ability to create new things in a spontaneous outflow of mind, which finds its expression in play, poetry and the arts. Abhinavagupta defined this intuition as the "insight incessantly scintillating with ever new forms It is by virtue of this intuition alone that one deserves the title of a poet." 73

The ability of the absolute to come up with ever-new forms is responsible for wonder; in both Paramädvaita and Neoplatonism, wonder is the mood of the Soul ascending towards the absolute in a mystical vision. Wonder (ekplexis) in Neoplatonism is a terminus technicus for a passionate state generated in the Soul by the divine beauty of the Good. ${ }^{74}$

The Soul, seeing the invisible as it were rejoices in itself, admires its appearing, and is astonished at it. And the mystics, in the most holy religious rites, before receiving mystical visions, are stricken with wonder, so in the realm of Intellect, the beautiful appears in advance, before communion with the good... ${ }^{75}$

71 Śiva, Mantreśvara, Mantramaheśvara, Vidyeśa, Vijñānākala, Pralayākala, Sakala. See TA, XV. 15.341. Dyczkowski, MBDL (2005), line 4229-35.

72 IPK, I.6.7. Also Sp.S.: ...māyāpramātrbhūmāvapi parameśvarasya prakāśātmanaḥ idam pañcavidhakrtyakāritvam sthitameva, pūrṇa tutatsaṃbandha sāvadhānavijñānaśälisaṃcetyam...

73 ...prajña navanavollekaśälin̄̄ pratibhā matā tadanuprānanājivadvarnanānipunah.....Cit. in: Gnoli, 1956, L. Thus Abhinavagupta is in aesthetics a strict intuitionist, same as Plotinus for whom the inner form (to endon eidos, Enn, I.6.3.8.) is responsible for both the creation and the reception of Beauty.

74 See e.g. Enn. I.6.7. 18 or ŠSV Transl. In Singh 1980, 52.

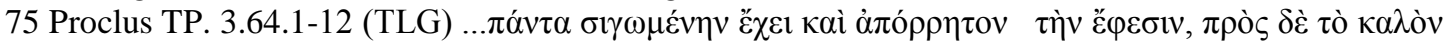

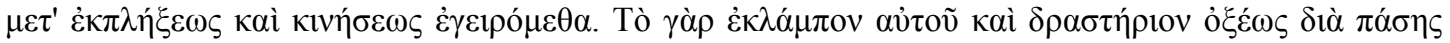

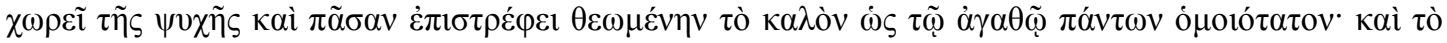


We find a description of this playful state in Enneads where the purified Soul of a philosopher oscillates between a complete unification with its ultimate subject and a partial departure from it. This leads to the state of wonder, which causes this unification again. ${ }^{76}$ It is described by similar terms in the Paramädvaita literal corpus e.g. by Śvasūtra: "The stations and stages of yoga constitute a fascinating wonder ".77 The commentator Kșemarāja adds "As a person is stuck with wonder ... even so there is pleasant surprise for the great yogi who notices in mute wonder an expansion of his entire complex of senses, as they come fully under the influence of the inner self, which is a mass of consciousness and full of unique, pre-eminent, ever new delight." 78

There are two contradictory doctrines on the nature of worldly beauty in Neoplatonism, which extend as far as Plato's work itself. One is entirely pessimistic about the presence of the Soul in the world of bodies as it considers the body to be the "grave of the Soul". The other is more optimistic in this regard as it considers the Soul to be on a divine mission in the realm of nature. Whereas the former is detectable in the middle dialogues, such as Phaedo, the latter can be found in the later ones, Timaeus, Phaedro or Symposium. Plotinus' positive account of sensual beauty and the emotional response it generates naturally takes its vitality from the latter, optimistic tendency. In this neoplatonic tradition, there is a direct proportion of the degree of being to the degree of beauty. "What does 'really exist' mean? That they exist as beauties! "79 Beauty in the sensual world is in fact the beauty of form:

From what source, then, did the beauty of Helen, whom men fought for, shine out, or that of all the women like Aphrodite herself? ... Beauty is not to be attributed to the size of the mass ... but it comes through the eyes as form alone. ${ }^{80}$

Or rather, beauty is not of form but of its source, i.e. of the Intellect, and ultimately of the Good. The hierarchy of beauty thus is only another side of the Neoplatonic ontology: "...first we must posit Beauty which is also Good, and from this immediately comes Intellect, which is beauty, and Soul is given beauty by Intellect... Soul makes beautiful the bodies which are spoken of as beautiful." 81 Thus we, as embodied Souls, have a unique opportunity to take beauty as a clue, which can return

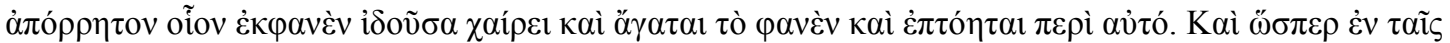

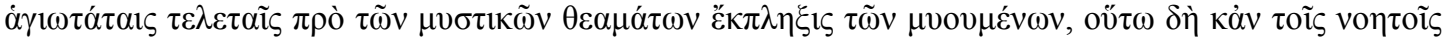

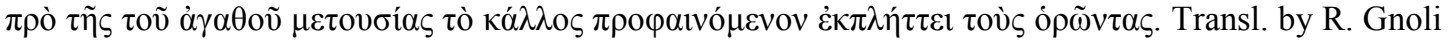
in: Gnoli 1956, XLVII.

76 Enn. V.8.11.1-11.

77 vismayo yogabhūmikāh ŚS. I.12., Singh 1980, 51-52.

78 Singh 1980, 52.

79 Enn. I.6.5.21 Again, some lines later: ...so for God, the qualities of Goodness and Beauty are the same...

80 Enn. V.8.2.9-27.

81 Enn. I.6.6.25-27. 
us to the spiritual world of Intellect or even beyond it. ${ }^{82}$ This transition is in fact "easy" since the Good is the ultimate source of all human desire. ${ }^{83}$

The origin of the emotion of love is, according to Plotinus, a "longing for beauty itself, which was there before in men's Souls". ${ }^{84}$ The very definition of love, therefore, is an activity of the Soul reaching after the good. ${ }^{85}$ In his system, beauty is the concrete way by which the transcendence in immanence is realized, since "If he (the god) is absent from the universe, he will be absent from you". ${ }^{86}$ Beauty, then, serves as a bridge by which the gap between the body, the Soul and the Intellect can be traversed.

Referring to Plato's Symposium, ${ }^{87}$ Plotinus differentiates between two Aphrodites, the Heavenly Mother of Eros (Ourania) and the common mother of Eros (Pandemos), with two corresponding kinds of love. The difference dwells in the lover's recognition of the ultimate source of beauty in the beloved object. But Plotinus does not brush aside the Eros of the common Aphrodite, wherein the lover fails to recognize the ultimate source of beauty and love in its true nature. He does note that a purer nature of bodily love is enjoyed in a "platonic" way, rather than in the way of fully developed sexual intercourse. ${ }^{88}$ But wise men, recollecting the source of beauty, focusing there, and thus practising a higher form of heavenly Aphrodite's erotics, do not condemn the lower form, since they know the playful creativity of the higher form: "but others, those who have recollected the archetype, venerate that higher beauty and also do not treat this earthly beauty with disrespect since they see in it the creation and play-thing of that other". ${ }^{89}$ It is to be remembered that the bewitching power of beauty, which can make the Soul ascend to its ultimate source, is apprehended in a delight and intense concentration on the vision ${ }^{90}$ reached by the enchanting power of love.

The aforementioned topic of divine play is also interesting since the doctrine of the Playfulness of the Absolute is central to some Indian traditions; this includes the famous Vaiṣnava cult of young Krșna but it also appears in Advaitavedānta, ${ }^{91}$ and especially in the Paramādvaita. In the passage cited above, Plotinus expresses something quite similar in describing vertical relations inside the systemic hierarchy: the creative energy of the higher levels can be described as play in relation to the lower. This idea remained unexplored and undeveloped in Neoplatonism, though an

82 In the system of Plotinus "we" can even penetrate, with the help of love, the level of Intellect and

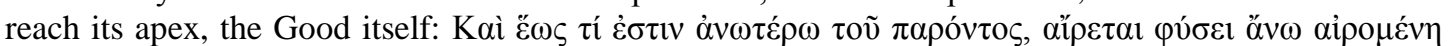

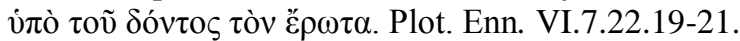

83 Enn. I.6.7.2.

84 Enn. III.5.1.17.

85 Enn. III.5.4.24.

86 Enn. II.9.16.25.

87Symp. 180d.

88 Enn. III.5.1. 17-18.

89 Enn. III.5.1.63-5.

90 Enn. III.5.3.9-10.

91 In the Advaita tradition the divine play as a reason of creation, as an answer on the question "why (of creation)" is present already in Brahmasütra (Br.S. II.1.33) 
option it remained. We can imagine this concept resolving many difficulties with the freedom of the first principle. ${ }^{92}$

In the context of Paramādvaita, the doctrine of the divine play (līlā, krī dāa) means that the dynamic absolute creates, sustains, and withdraws the world freely and from its own will, playfully hiding and enfolding itself in it. ${ }^{93}$ This play is real, ${ }^{94}$ and as such it manifests the unlimited freedom of its source. ${ }^{95}$ Since the border line of micro/macro cosm is a bit fuzzy in this radical Kashmiri holism, it is no wonder that we also find the doctrine of play on the level of everyday orthopraxis. Here, divine play is a mode of being of an enlightened yogi, who playfully abides in the world of samsāra, performing all his activities in a playful way and by such means remains untouched by the misery of samsāra - even in the middle of its wild stream. ${ }^{96}$ Spontaneity is another side of such playfulness, as discussed above.

Yet there is another connected topos belonging to the semantic field of 'play', which we find on the both sides of our comparandum. It is the world as theatre with the Soul as an actor. This simile occurs both in Neoplatonism, e.g. "...but in a truer poetic creation, which men who have a poetic nature imitate in part, the Soul acts, receiving the part which it acts from the poet creator", 97 and quite frequently in the Paramādvaita, wherein e.g. "the Self is an actor, the stage is the inner Soul, the senses are spectators", to cite the most respected locus communis on this topic. ${ }^{98}$

Abhinavagupta and others further elaborate this simile using Indian aesthetics, namely the school of rasaväda, which considers "emotional juice" (rasa) to be the ultimate goal of artistic performance. ${ }^{99}$ All other dramatic or poetical means such as plot, figure, dance, music etc., merely serve the transmission of rasa. This requires genuine active intuition (pratibh $\bar{a}$ ) on the side of artist-creator and the same portion of passive intuition on the side of spectator. ${ }^{100}$

92 E.g., Enn VI.8., which is one of the famous treaties on freedom of the first principle. Its conclusioun

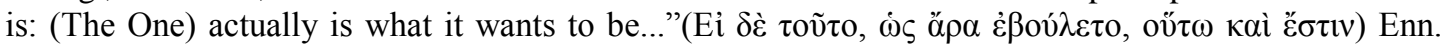
VI.8.13.9.

93 Creation (ș̣sti), maintenance (sthiti), withdrawal (saṃhrti), covering (tirodhana) and grace (anugraha) are main activities of Paramādvaitic absolute.

94 Unlike in Advaita vedānta, where this play would be interpreted as illusion māya. See Baumer 1995, 37-38.

95 TA 101, heyopādeyakathāvirahe svānandaghanatayocchalanam | krị̄̂a sarvotkarṣeṇa vartanecchā tathā svatantratvam

96 SKV 29:... iti vā yasya samvittị̆ krị̄ātvenākhilam jagat | sa paśyansatatam yukto jūvanmukto na samśayah... See SK. II.5. Singh 1980, 119. See also Dyczkowski 1992, line 165.

97 Enn. III.2.17.28. Transl. by Armstrong, See also Proclus, De decem dub. 60 (TLG ed.).

98 ŚS. III.9-11:nartaka ātmā / rañgo'ntarātmā / prekṣakāṇinndriyāṇi Dyczkowski, MBDL 2005, line 73-75.

99 Based on Bharatamuni's Nātyaśāstra. See 6.15. "The following eight rasas should be remembered in drama: loving, ridiculous, sad, angry, heroic, terrible, disgusting and wonderful. "śrngāarahāsyakaruṇā raudravīrabhayānakāh / bībhatsādbhutasamjñau cetyaștau nātye rasāh smrtāh (Abhinavagupta adds to this list a ninth, peaceful rasa, as either another member of the raw, or as a basis of the remaining eight rasas. See Masson 1969,91-151).

100 Gnoli 1956, L-LI, n.1. 
The tasting of rasa takes an active part within the spectator's Soul. In fact, it is a tasting of the delight of one's own consciousness (svasamvidcarvaña). ${ }^{101}$ This delight is revealed to the concentrated "unobstacled" consciousness (nirvighna cit). ${ }^{102}$ Abhinavagupta describes this state in similar terms both in his aesthetical and philosophical works: as the repose in one's own self (svātmaviśrānti) which is caused either by the flow of the emotional juice (rasa) or by yogic meditation. ${ }^{103}$ Occasionally, he compares both states: the non-difference of consciousness (samvidabheditatva) reached by aesthetic delight (rasāsvāda) and the fullness of consciousness (samvidpūrnatva) reached step by step in yoga (brahmāsvāda). ${ }^{104}$ As the ultimate sense of drama is tasting the essence, rasa, i.e. one of the 8 primary emotions, so too the ultimate sense of theatrum mundi is tasting the essence or "juice" of it, i.e., consciousness. ${ }^{105}$

The Supreme Lord's unique state of emotivity is the outpouring of pure Being. It is manifest as the brilliance (sphurattā) of the universe which, if we ponder deeply, is the single flavour (ekarasa) of the essence of Beauty which is the vibration of the bliss of one's own nature. ${ }^{106}$

The last related metaphor to which I would draw attention is that of the dance of the Soul. On both sides of our comparison, it serves an expression of the dynamic nature of consciousness. Thus according to Plotinus, Time (chronos) belongs to the sphere of Soul, and is considered to be the moving image of eternity. The meaning is explained and ethymologized by Proclus as a circular dance (choros) around the Intellect (choros-nous). ${ }^{107}$ We find the same metaphor expressing the same thought in Paramādvaita, where Time $(k \bar{a} l a)^{108}$ and its constantly changing nature is described

101 See Masson 1969. 42-43.

102 "Once one has overcome distraction, the pleasure one enjoys through the sentiments of love etc., expressed in poetry or drama for example, differs from the pleasure derived from sense object. This is because (one gains access to it) by removal of such obstacles as anticipation of possible personal gain. So, once freed of these impediments, the experience (pratiti) is one of relishing (rasanā), tasting (carvana) or contentment (nirvrti) and is, in fact, repose in cognising subjectivity." (Abhinavagupta, iśvarapratyabhijñāvivrtivimarśin̄̄, Transl. in Dyczkowski 1989, 148.)

103 Masson 1969. 42-43, 153-164.

104 ...kșaṇake tattaddrașțtasamvidabheditām || kramoditām sadya eva labhate tatpraveśanāt yogābhyāsakramopāttām tathā pūrṇām svasamvidam \| Dyczkowski, MBDL (2005), line 16065-68. But in fact "..the bliss that comes from finding rest in God is far superior (prakrsyate), ...aesthetic pleasure (rasāsvāda) is only reflection (avabhāsa) of drop (vipruș) of that mystic bliss." (Abhinavagupta, Dhvynyālokālocana, transl in Masson, 1969, 158)

105 ...The so called supreme bliss, the lysis, the wonder, is therefore nothing but a tasting, that is, a cogitation in all its compact density, of our own liberty... Gnoli 1956, XLIV. See also Dyczkowski 1989, 147-8.

106 Mahārthamañjarī, transl. In Dyczkowski 1989, 51.

107 In Tim. III.9.16-18; 28.00. Plotinus used the metaphor of circular dance for the movement of stars (considered as ensouled bodies). However, this movement is an expression of perfect harmony and eternal life of All-Soul. (Enn. IV.4.8.). In general, the One is depicted as a point, the Intellect as a circle, and the Soul as a moving circle. (Enn. IV.4.15.)

108 According to the nomenclature of the system, kāla is one of 6 "coverings" which cover the fettered consciousness of an embodied Soul. (IPK+IPKV, III.2.4-19.) But here we focus on the dynamic nature of consciousness in general. 
as the wheel of energies, (śakticakra) ${ }^{109}$ and understood as a sequence of $12 \mathrm{ka} l \bar{l} \mathrm{~s}^{110}$ This everlasting movement of power, which expresses itself in the changing forms of the wheel of energies that turns with each single act of cognition, is often metaphorically depicted as dancing (nrtyantī) goddess, Śakti, the power of the absolute, as she moves round Siva, the eternal witness, the absolute itself. ${ }^{111}$

The key term, which bridges the aesthetics and philosophy of Paramädvaita, is camatkāra (verbatim: savouring, meaning: astonishment, wonder). It is a mood into which God is driven by his own Śakti. ${ }^{112}$ Utpaladeva and Abhinavagupta use it as a near synonym for reflective awareness (vimarśa). ${ }^{113}$ There is a good reason for this: the reflective awareness is a savouring of the pure, expanding consciousness. This is accompanied by wonder and astonishment. ${ }^{114}$ It is cit-śakti in her highest form and as such she is often hailed. ${ }^{115}$

The enchanting power of beauty naturally concentrates the mind and brings the attentive yogi towards its vibrant source, which actually lays within himself. This is why we are often advised in Tantras ${ }^{116}$ to follow an aesthetic experience of whatever kind (food, art, music, and poetry, as well as love affairs and other erotic situations). E.g., in Vijñānabhairavatantra where, after several suggestions to concentrate on different sources of sensual beauty, we find the teaching summarized: "Wherever the mind finds joy manifested, that should be contemplated (by a yogi) since that is the true nature of ultimate joy (which is Siva, the dynamic absolute itself)."117

109 SK I.1, SKV 3.

110 E.g. by Kșemarāja in SpN: Singh 1980 7,13.

111 E.g.: SKV 164.: He (Śambhu, Siva), like a newly wedded husband, constantly gazes at His beloved power Who, although inwardly undivided, dances in many ways outside (Her) own nature, (Her) diverse forms and seemingly new aspects conceived in the varied light of thought. (Transl. By Dyczkowski 1981, 126)

112 Abhinavagupta in Abhinavabhārat̄̄ gives a classical example of camatkāra: ... "Viṣnu is still today in a state of camatkāra: how, oh how is that limbs of Laksmī, which are like the borders of a limb of the moon, have not been convulsed by mount Mandara?" That is to say, what is called camatkāra is an uninterrupted state of immersion ( $\bar{a} v e s ́ a)$ in an Enjoyment... (Translated in Seturaman, 1992, 47).

113 IPKV 1.5.11, For a detailed summary of the semantic field of camatkāra, see also n. 23 in Torella 2002, 118-119.

114 “...The words wonder (camatkāra), immersion (nirveśa), tasting (rasanā), sampling (āsvādana), enjoyment (bhoga), accomplishment (samāpatti), lysis (laya), rest (viśrānti) etc., mean simply a form of consciousness completely free from any obstacles." Abhinavabhäratī, translated in Seturaman, $1992,49$.

115 Abhinavagupta e.g. in PTV comments on Utpaladeva, IPK I.6.7 cited above (n. 31): svātmacamatkārarūpā śäktollāsamayaviśvāmarśanarūpa (..it is the wonder of once own self, the playful power of all forms of reflective awareness..) Dyczkowski, MBDL (2005), line 572-573. In the same text he hails the consort of Śiva ...svātantryaikarasāveśacamatkāraikalakșanā parā bhagavatī ... (the supreme goddess characterized by only sign of wonder which originates only from immersion into the essence of freedom) Dyczkowski, MBDL (2005), line 4610.

116 Non-dualistic tantras are an older, revealed, anonymous layer of the younger "scholastic" one, as represented by Abhinavagupta and other commentators.

117 V.Bh. 74: yatra yatra manastuștirmanastatraiva dhārayet | tatra tatra parānandasvarūpam sampravartate \| 
Keeping all this in mind, we can conclude that for both Neoplatonism and Paramädvaita aesthetic beauty and the emotional response it generates (ekplexis, camatkāra) are means which help the Soul, first to concentrate its mind-stream and forget worldly affairs, then to follow the impulse within and reflect directly upon herself. This movement might even lead to union (henosis, samāveșa) with the source of all beauty, consciousness itself. In both systems this source lays beyond the form through which it is communicated. Both systems advise the use of the enchanting power of beauty in a contemplative mental experiment as a means by which to shift consciousness from a discursive modus of mind towards non-discursive intuition: in terms of Neoplatonism, this means the ascent from sense perception (aisthesis) and discursive thinking (dianoia) towards intuitive seeing (noesis); in Paramādvaita the same movement is from direct experience (pratyakșa) and the mental construct it generates (vikalpa), towards intuition (pratibha $)$ and reflective awareness (vimarșa). The similar doctrinal base is moreover occasionally expressed by the similar metaphors, like that of theatrum mundi, or the dance of the Soul.

Thus one of the most striking features of both systems is their ability to incorporate sensual beauty and the emotional response generated by it, within their metaphysical and soteriological frames. Both Neoplatonism and the Paramädvaita do so in an analogical socio-historical context, as both faced an orthodox ascetic intellectual environment which avoided any contact with the world of sense and its beauty, considering it a dangerous trap of illusion. There is perhaps no coincidence that both Plotinus and Abhinavagupta were great philosophers and aestheticians at once. In both cases their doctrines were addressed to educated laymen, not monks of some particular religious sect. The philosophers did not wished to cut the social branch that they were sitting on. And so the world in its physical form was not intellectualized away but saved by contemplative focus on its beauty.

\section{FURTHER PERSPECTIVES OF RESEARCH ON NEOPLATONISM AND PARAMĀDVAITA}

If a high degree of correspondence of Neoplatonism and Paramädvaita has been successfully demonstrated, a wide field opens up that has not yet been a subject of study, as far as I know, neither in this nor in any other text. First, how far might this correspondence progress and what are its limits? I am, of course, conscious of the basic nature of the Platonic tradition, which is "objectivist", as well as the nature of Paramädvaita, which is "subjectivist". But some passages in Enneads can be interpreted as steps towards non-dual, subject-based thinking as we know it from India, where some Advaita traditions correspond more or less accurately with their doctrines. We might conclude that some of the ideas of Enneads can be found in the scriptural corpus of Paramädvaita, where we can find them perhaps in a developed and radicalised form. We can also find corresponding elements within the notion of the dynamic absolute, the radical subjectivism wherein the "outer world" depends on the Soul whose freedom is both its natural state and the ultimate goal of human life, the doctrine of multilevelled subjectivity connected with the doctrine of multileveled 
speech, the doctrine of mutual interdependence or even interpenetration of everything with everything else. This list merely summarizes some of the most important topics, most of which have been discussed above; and all this needs further discussion by specialists in each subject. But if our thesis stands up such discussion, what further questions might be asked?

How is it possible that this philosophical doctrine seems to have travelled across geographical and cultural boundaries with such unbelievable ease? This might be explained either by the nature of the subject itself, namely the nature of the mind as it appears under a focused and systematic introspection, which is the method par excellence of both compared systems, or by a cross-cultural exchange of ideas based on real contact on oral or textual level. Let us return once more to F. Staal and apply one of his conclusions here: since direct textual parallels, e.g. translations, seem difficult to be found, the question of real contact may remain forever open as its answer more or less depends on the personal preferences of each interpreter. ${ }^{118} \mathrm{We}$ could take the first path and presume that doctrinal parallels are derived from the nature of the mind itself; we are thus led to the old doctrine of eternal philosophy (philosophia perennis or theologia prisca), originated in Corpus hermeticum and formulated e.g. by the Renaissance Platonist Marsilio Ficino: an ethernal universal wisdom which has been imparted to all nations by their prophets. ${ }^{119}$ Taking the path of "influence" would on the other hand lead to an increasingly detailed study of history with a proportionally increasing degree of speculative theorising based on the growing amount of material of such study.

I began my text by promising for methodological reasons to abstain from hypothesizing about the influence between these systems; however, we cannot altogether exclude the possibility that this occurred. Historical and archaeological research in the Kashmiri region might reopen the question from an alternative perspective. Can we expect the rise of a "Hellenistic hypothesis" from the ruins of the "Orientalist"? Keeping in mind the unique Greco-Indian cultural mixture of northern Bactria, we have a double reason for not excluding such option.

I would be especially interested in exploring a further question. If we insist on abstaining from questions of influence, can we explain the similarity by use of structural reason? Both systems are a late stadium of a long existing tradition of monistic idealism, each of its kind. Could their similarity be caused by their similar polemical interaction with a similar opponent? What about the influence of criticism from a sceptical position on such an idealism? From what we know of the history of both systems, they were under fire by sceptics and their anti-substantionalistic or generally anti-metaphysical and anti-dogmatic dialectic. ("Nothing is in itself more this than that"). ${ }^{120}$ With one, it was the polemic with Mahāyāna Buddhism. ${ }^{121}$ With

118 Staal 1961, 23.

119 We could find the same concept under the name 'sanātana dharma' in India.

120 In its highly formalized form the skepsis condensed in both tradition to the "fourfold formula":

Nāgārjuna: One should say of each thing that it neither is, nor is not, nor both is and is not, nor neither is nor is not. 
the other, it was the polemic with late-antic scepticism. ${ }^{122}$ Recent scholarship suggests that the middle way school (Mādhyamika) of Nāgārjuna, with its sudden blossoming of Buddhist skepsis based on developed dialectic.

...(Which) originated in the Greco-Buddhist communities of India through a conflation of the Greek Democritean-sophistic-sceptical tradition with rudimentary and unformalized empirical and sceptical elements already present in early Buddhism. ${ }^{123}$

We might hypothesize that the reaction of monistic idealism to devastating sceptical arguments that target its notion of substance and therefore all its doctrines, be it permanent, immortal Soul, or omnipotent, creative absolute, ${ }^{124}$ might be to develop an emphasis on the dynamic nature of the first principle, based on radical holism and personal contemplative experience. Greek philosophers used the weapon of dialectic with two contradictory motives. The metaphysical branch, represented by the Plato, Parmenides and partly by the Academy, used dialectic to destroy belief in the reality of conditioned being so that a mystical intuition of unconditioned being might be ensured, whereas the critical branch, represented by Democritus, Pyrhon and Sextus, used dialectic to free the mind from the belief that mind-concepts correspond to reality, so as to develop a suspension of belief (epoche), followed by an emotional balance of the mind (ataraxia). ${ }^{125}$

In India, the critical branch would roughly correspond to early Mahāyāna Buddhism, whereas the metaphysical branch would correspond to Advaita stream of Indian philosophical thinking, including to some extent, with its uncompromised emphasis on transcendence-in-immanence and blending of realism and idealism. Paramädvaita can be rather seen as a synthesis of both views, although with obvious prevalence of metaphysical over the critical.

The "structural hypothesis" is further supported by the fact that the Mahayyana school has undergone the same development, i.e. a shift to a metaphysical position of essentialism. Thus Mahāyāna in its later stages, in order to emphasize the activity of Buddha-nature that expresses itself in acts of wisdom and compassion, tried to overcome early Mādhyamika scepticism by the Tathāgatagarbha doctrine. According to this doctrine of the germ of Buddhahood (Tathägatagarbha), the highest Buddha-nature (dharmakāya) as the eternal innermost core of reality is

Sextus Empiricus: We should say of each thing that it no more is than is not, than both is and is not, than neither is nor is not.

121 See Kawajiri 2006, Ratie 2010.

122 Mostly Sextus Empiricus, See Kuhn 2008. The similarities of Buddhist and Greek scepticism is discussed (e.g.) in Evilley 2002, 450-490.

123 Evilley 2002, 503. "It is very suggestive that the areas of India where Mahāyāna Buddhism is most commonly supposed to have arisen - Gändhāra, Kaśmīr and Amarāvatī - are the areas where the Greek culture penetrated most deeply." Evilley 2002, 502.

124 The (sceptical) doctrine of indeterminacy (Grk. aorista, "lack of boundary or definition" Skt. svabhāva śünyatā) is simultaneously a critique of ontological claims of absolute Being or non-Being, of epistemological claims for knowledge...and of the view there is a language-reality isomorphism.

125 Evilley 2002, 420. 
immune to the sceptic dialectic of Mädhyamika, for which everything is relative, mind-only (vijnāptimātra), and thereby without its true nature (asvabhāva), lacking the self (anātma) and impermanent (anitya). ${ }^{126}$

Consideration of the structural question is beyond the reach of this text, but let me hope that it might serve as a ladder for those who next approach such an unexplored landscape: "When intellectual curiosity climbs higher and higher and sees the truth without getting tired, this is because of the ladders of thought built by earlier writers." 127

\section{ACKNOWLEDGEMENTS}

I would like express my special thanks to peer reviewers from the journal Comparative Philosophy during double-blind peer review process, a procedure that strengthened the message of my text and contributed to its final version. I would also like to thank to all my proofreaders (Gerald Ostdiek, Petr Duda, and Damon del Strother) whose valuable comments helped to clarify the text and make it more accessible to the reader. I would like to give my heartfelt thanks prof. Raffaele Torella and prof. Mark Dyczkowski, those excellent scholars of Indian philosophy who encouraged me to continue my work, inspired me with their own work and provided me with occasional consultation and help. Finally I would like to thank to the Department of Philosophy and History of Sciences, Charles University, Prague, where I as a Phd student started to work on this text.

\section{REFERENCES}

\section{PRIMARY SOURCES WITH ABBREVIATIONS}

Abhinavabhāratī (ABh): Abhinavagupta, ed. by M.Ghosh (1967), Nātyaśāstra, (Calcuta: Manisha Granthalaya).

Enneads (Enn.): Plotinus, trans. A.H.Armstrong (1966-1988), Enneads, 7 vols. Including Greek text of Henry-Schwyzer (Cambridge: Harvard university press).

Elementatio Theologica (ET), Proclus, ed. and trans. E.R. Dodds (1944), The Elements of Theology (Oxford: Clarendon press).

İ́varapratyabhijñāvimarśin̄̄ (IPV), Abhinavagupta, ed. and trans. K.C.Pandey (1998), Bhāskarī: Part 3, (Varanasi: Sampurnanad Sanskrit University).

Íśvarapratyabhijñākārikā and vrtti,(IPK, IPKV) Utpaladeva, ed. and trans. R. Torella (2002), (Delhi: Motilal Banarsidass).

Mahārthamanjarī (MM), Maheśvaranānda, ed. by V.V.Dvivedi (1972), (Varanasi: Yogatantra-Ratnamālā)

126 King 1995, 222-224.

127 ABh I.278, Gnoli 1965, 12, Transl. in Masson 1969, 2. 
Muktabodha Digital Library, (MBDL) ed. and supervised by Mark Dyczkowski, http://www.muktabodha.org, (2010).

Pratyabhijñāhrdayam (PH): Kșemarāja, trans. J.Singh (1963), The Doctrine of Recognition, (Varanasi: Vishveshvaranand Institute) .

Parātrīmśikhāvivaraṇa (PTV) Abhinavagupta, in Kashmir Series of Texts and Studies 18, ed. by Mahāmahopadhyāya Mukund Rām Shāstrī (1918), (Bombay, Tatva Vivechaka press).

Parātrīmśikhāvivaraṇa: Abhinavagupta, trans. Jaideva Singh (1988), (Delhi: Motilal Banarsidass).

Spanda-Kārikā + Spanda Nirnaya (SK, SpN), Vasugupta, trans. by Jaideva Singh (1980), Spanda-Kārikās, The Divine Creative Pulsation, the Kärikās and the Spanda Nirnaya of Kșemarāja, (Delhi: Motilal Banarsidass).

Spandakārikā vṛti + vivṛti (SKV), Kallața bhațta, ed. by J.C. Chatterji, (1916) in Kashmir Series of Texts and Studies 5, (Śrīnagar: The state department of Jammu and Kashmir)

Spandasaṃdoha (Sp.S), Kșemarāja, ed. by Mahāmahopadhyāya Mukund Rām Śāstrī (1917), in Kashmir Series of Texts and Studies 16, (Bombay: Tattva Vivechaka press).

Siva Sūtra, (SS) trans. Jaideva Singh (1995), Siva Sūtras, the Yoga of Supreme Identity, text of the Sütras and the commentary Vimarśinī of Kșemarāja, (Delhi: Motilal Banarsidass).

Tantrāloka (TA): Abhinavagupta, in Kashmir Series of Texts and Studies 23-24, ed by Mahāmahopadhyāya Mukund Rām Śāstrī (1918), (Allahabad: Tattva Vivechaka press).

The Thesaurus Linguae Graecae (TLG) (Digital Library of Greek Literature), University of California, Irvine: http://www.tlg.uci.edu, (2010).

Upanișads:, ed. and trans.S. Radhakrishnan (1994), (Delhi: Harper Collins).

Vijñānabhairava (V.Bh), commentaries by Kșemarāja, Śivopadhyāya, Anandabhațta, Kashmir Series of Texts and Studies (KSTS) 8, ed by Mahāmahopadhyāya Mukund Rām Śāstrī (1918), (Bombay: Tattva Vivechaka press).

Vākyapadīya (VP) Bhartrhari, Word index to the Vākyapadīya of Bhartrhari, together with the complete text of the Vākyapadìya, Saroja Bhate (1992), Niedersächsische Staats- und Universitätsbibliothek Göttingen: www.sub.uni-goettingen.de, (2010).

\section{SECONDARY SOURCES (AUTHORS INDEX)}

Armstrong, A. Hilary (1936), "Plotinus and India", Classical Quarterly, 30, (3-4), 2228.

Baumer, Betina (1995), "The Play of the three Worlds, the Trika concept of $\bar{l} \vec{l} \vec{a}$ ", in William S. Sax (ed.): Gods at Play (Oxford: Oxford University Press), 35-50. Brehier, Emile, (1936), The Formation of our History of Philosophy." in Philosophy and History, essays presented to Ernst Cassirer. Ed. by Raymond Klibansky and HL Paton, (Oxford: Clarendon Press). 
Dodds, Eric Robertson (1953), The Greeks and the Irrational (Berkeley/Los Angeles: University of California Press).

Dodds, Eric Robertson (1928), "The Parmenides of Plato and the Origin of the Neoplatonic One", Classical Quarterly, 22, (3-4), 129-142.

Dodds, Eric Robertson (1933), Proclus: Elements of Theology (Oxford: Clarendon press).

Dyczkowski, Mark (1991), The Aphorisms of Śiva: with a commentary by Bhāskarācārya, (Varanasi: Dilip Kumar Publishers).

Dyczkowski, Mark (1989), The Doctrine of Vibration: An Analysis of the Doctrines and Practices of Kashmir Shaivism (New York: State University of New York press).

Dyczkowski, Mark (1992), The Stanzas on vibration: the Spandakarikā with four commentaries: the Spandasamdoha by Ksemaraja, the Spandavrtti by Kallațabhațta, the Spandavivrtti by Rājānaka Rāma, the Spandapradīpikā by Bhagavadutpala (New York, State University of New York press).

Dyczkowski, Mark (1990), Self Awareness Own Being and Egoity, (Varanasi: Ratnapress).

Dyczkowski, Mark (2005), Muktabodha Digital Library, (MBDL) ed. ans supervised by Mark Dyczkowski, http://www.muktabodha.org, (2010).

Evilley, Thomase, Mc (2002), The Shape of Ancient Thought: Comparative Studies in Greek and Indian Philosophies (New York: Allworth Press).

Filliozat, Jean (1964), The Classical Doctrine Of Indian Medicine: Its Origins And Its Greek Parallels, (Delhi: Munshiram Manoharlal).

Fowler, Harold (1921) Plato in Twelve Volumes, trans. by. Fowler. (Cambridge: Harvard University Press)

Gnoli, Raniero (1956), The Aesthetic Experience according to Abhinavagupta (Varanasi: Chowkhamba Sanskrit Series Office).

Hacker, Paul (1992), "Cit and Nous in Advaita and Neoplatonism", in Baine Harris (ed.), Neoplatonism and Indian Thought (New York: State university of NY),161181.

Hadot, Pierre (2002), What is Ancient Philosophy, transl. by Michael Chase (2002), What is Ancient Philosophy (Cambridge: Harvard University press).

Hankey, Wayne J. (2006), One Hundred Years of Neoplatonism in France: A Brief Philosophical History, (Leuven/Paris/Dudley: Peeters)

Chlup, Radek, Proklos, (2009), (Prague: Herrman)

Kawajiri Yohei, (2006), "A critique of the Buddhist doctrine of self-awareness in the Pratyabhijña school" in Journal of Indian and Buddhist Studies 54,3. 218-220.

King, Richard, (1995) Early Advaita Vedānta and Buddhism: The Mahāyāna Context of the Gaudapādīya-kārikā (Albany: State University of New York Press)

Kenna, Mac, Stephen (1969), Plotinus, The Enneads translated (London: Faber and Faber).

Kuhn, Wilfried (2008), Quel savoir après le scepticisme? Plotin et ses prédécesseurs sur la connaissance de soi, (Paris: Vrin). 
Lakshman, Joo (2002), Vijñānabhairava, The Practice of Centering Awareness, Commentary by Swami Lakshman Joo (Varanasi: Indica Books).

Lusthaus, Dan (2002), Buddhist phenomenology: a philosophical investigation of Yogācāra Buddhism (London: Routledge).

Lusthaus, Dan (2002), What is and isn't yogācāra, http://www.acmuller.net/ yogacara/articles/intro-uni.htm (2011)

Masson, Moussaieff (1969), Śāntarasa and Abhinavagupta's Philosophy of Aesthetics (Poona: Bhandarkar Oriental Research Institute).

Merlan, Philip (1953), From Platonism to Neoplatonism (Hague: M. Nijhoff).

Pandey, Kanti Ch. (1963), Abhinavagupta: An Historical and Philosophical Study (Varanasi: Chowkhamba Sanskrit Series Office).

Pandey, Kanti Ch. (1998), Bhāskarī: Part 3 Íśvarapratyabhijñāvimarśinī (Varanasi: Sampurnand Sanskrit University).

Ratie, Isabelle (2010), "The Dreamer and the Yogin - on the Relationship between Buddhist and Saiva Idealisms" in Bulletin of the School of Oriental and African Studies 73 (3) 437-478.

Sanderson, Alexis (1985), "Purity and Power among the Brāhmans of Kashmir", in M. Carrithers, S. Collins and S. Lukes (eds.), The Category of the Person: Anthropology, Philosophy, History (Cambridge: Cambridge University Press), http://alexissanderson.com, 2010.

Sanderson, Alexis (1990), "Śaivism and the Tantric Traditions" in The World's Religions, ed. by S. Sutherland, L. Houlden, P. Clarke and F. Hardy, (London:Routledge), http://alexissanderson.com, 2010.

Seturaman, V.S. (1992), Indian Aesthetics, (Madras: Macmillan India Ltd.)

Singh, Jaideva (1963), The Doctrine of Recognition: A Translation of pratyabhijñāhrdayam, Kșemarāja, (Varanasi: Vishveshvaranand Institute).

Singh, Jaideva (1980), Spanda-Kārikās, The Divine Creative Pulsation (Delhi: Motilal Banarsidass).

Singh, Jaideva (1995), Siva Sūtras: The Yoga of Supreme Identity: text of the sūtras and the commentary Vimarśinī of Kșemarāja translated into English, (Delhi: Motilal Banarsidass).

Staal, Fritz (1961), Advaita and Neoplatonism, (Madras: University of Madras).

Torella, Raffaele (2002), Íśvarapratyabhijñā kārikā and vrtti-Critical edition and annotated translation (Delhi: Motilal Banarsidass).

Wallis R.T. (1972), Neoplatonism, (London: G. Duckworth).

Wolters, Albert M. (1982), "A Survey of Modern Scholarly Opinion on Plotinus and Indian Thought", in R. Baine Harris (ed.), Neoplatonism and Indian Thought, (Virginia: State university of NY), 293-309. 